\title{
DIGITAL DRAWING DESIGN BASED ON LOCAL WISDOM IN PRODUCTION ORALE AVANCÉE COURSE
}

\author{
Jubliana Lamria Sitompul \\ Universitas Negeri Medan
}

\begin{abstract}
This study aims to design and develop learning media in the Production Orale Avancée course using digital images based on local wisdom in Medan in accordance with the demands of DELF level B1 French speaking competence. On the other hand, this study also aims to determine student learning outcomes using digital image learning media in the Production Orale Avancée course. The sample used is 30 students from the fifth semester The research method used is the Research and Development (R\&D) method with the development procedure of Thiagarajan (1945:5) by carrying out four stages, namely collecting information and data, planning, developing learning media, expert validation of the media and material included ..After the four stages were carried out and declared feasible by the validator, the learning media was tested on students in the classroom. The results of material validation in the first stage are $92.30 \%$ and $100 \%$ in the second validation stage. While the results of the media validation are in the first stage, namely $90.9 \%$ and $100 \%$ in the second stage.
\end{abstract}

Keywords: speaking, learning media, digital image, local wisdom.

\section{INTRODUCTION}

At several universities in Indonesia, there is a choice of French language study programs in the fields of education and literature. In the learning process, there are four core competencies, namely listening, speaking, writing, and reading that must be mastered by students as one of the graduate criteria. Listening and reading are skills in receiving information, while speaking and writing are skills in producing information with words.

At Medan State University, the four competencies are tested on students through the DELF exam with a minimum level of B1. So, to achieve the graduation criteria, students are expected to master these four skills.

However, in practice, speaking skills have not yet reached the expected competencies. Bergström (2017: 31) "speaking skill is something that must be mastered by students when learning a language because it covers almost all of its components". Boissonette (2001:71) add that students can pour and explain the material they have learned by speaking. In addition, the purpose of teaching speaking is to guide teachers and students to use the target language as a common language in the classroom environment even in everyday life.

The Production Orale Avancée course is one of the core courses in the RPS, but the percentage of students who communicate using French in class is still low. Emiliana (2013: 8) says that "students' speaking skills can describe their language knowledge so that it can be practiced in real life in the form of daily interactions and most often a person's first impression is based on his ability to speak fluently and completely".

Based on observations made by researchers when teaching in the Production Orale Avancée class, most of the students who participated in the class still had difficulty speaking and expressing their opinions, ideas and ideas regarding the ongoing learning material. Students experience difficulties or difficulties in expressing French words, for example students who take a long time before starting to speak, their eyes are still blank, and they turn left and right to ask their friends what they should say. 
The constraints mentioned above are caused by various reasons. Starting from students who are shy, lack of lexical/vocabulary, until students do not have ideas that can be developed as material to be discussed, to the lack of speaking practice outside the classroom.

Based on the explanation of the problems above, one alternative is the use of visual media, namely pictures in the process of learning to speak. Before entering the lesson, the lecturer has prepared in advance the pictures related to the learning material. After the lecturer explains the material as usual, students will be directed to voice their opinions. They can see the help according to the description in the picture. So, they speak based on the content and description in the picture. In this way, it is hoped that the speaking class will be more lively and active than before.

The images used have been modified according to the theme of local wisdom in the city of Medan. It aims to develop skills that are tailored to the characteristics and peculiarities of the surrounding area. This component of local wisdom is determined by the education unit which refers to the government's appeal in accordance with the law.

The images used are also digital-based along with technological developments to influence and bring changes in aspects of life, especially in the world of education. Education continues to evolve with the times. Learning media such as LCD projectors, multimedia rooms, and internet access are signs of the times, especially computerized ones entering the world of education.

Based on the explanation of the paragraphs above, the researcher is interested in conducting a study entitled "Design of Digital Drawings Based on Local Wisdom in the Production Orale Avancée Course"

\section{RESEARCH METHOD}

Based on the title of this research, the method used in this research is Thiagarajan's Research and Development that called 4D, with four steps. These are:

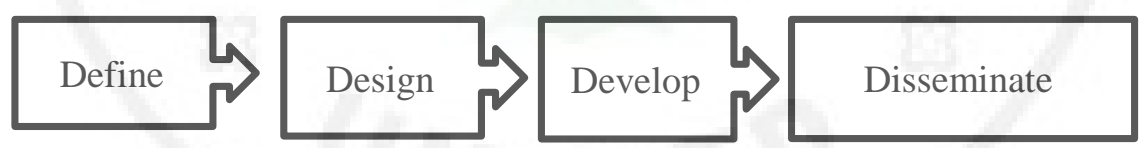

\section{FINDINGS AND DISCUSSION}

\section{Define}

This initial step is used to determine student needs related to the use of digital images in the classroom. The results of the needs analysis can be seen in the table below:

Table 1Results of needs analysis questionnaire

\begin{tabular}{lcc}
\hline Questions & The answer "Yes" & The answer "No" \\
\hline $\begin{array}{l}\text { In the learning process, Production Orale } \\
\text { Avancee uses the learning media. }\end{array}$ & $3(10 \%)$ & $27(90 \%)$ \\
$\begin{array}{l}\text { The learning media used by the lecturer is } \\
\text { very appropriate to the actual situation. }\end{array}$ & $5(17 \%)$ & $25(83 \%)$ \\
\hline $\begin{array}{l}\text { Learning media used by lecturers will be } \\
\text { very interesting with clear animations, } \\
\text { pictures, videos and audio. }\end{array}$ & $29(96,6 \%)$ & $1(3,3 \%)$ \\
$\begin{array}{l}\text { The use of image visualization in the } \\
\text { learning process in the classroom can } \\
\text { increase activeness and enthusiasm for } \\
\text { learning }\end{array}$ & $28(93,3 \%)$ & $2(6,6 \%)$ \\
$\begin{array}{l}\text { If the lecturer uses learning media in the } \\
\text { form of digital images based on local } \\
\text { wisdom in the learning process in the }\end{array}$ & $30(100 \%)$ & $0(0 \%)$ \\
\hline
\end{tabular}


classroom, it can increase activeness and enthusiasm for learning

\section{Design}

This is the initial stage in designing digital images based on local wisdom. In this stage, the researcher begins to design teaching materials and then makes a digital image arrangement as a support in the teaching materials. Making the drawing begins with the design of the sketch. The Drawin Tablet used is a rough Dip Pen (381) with a normal background of $100 \%$ as shown in the image below:
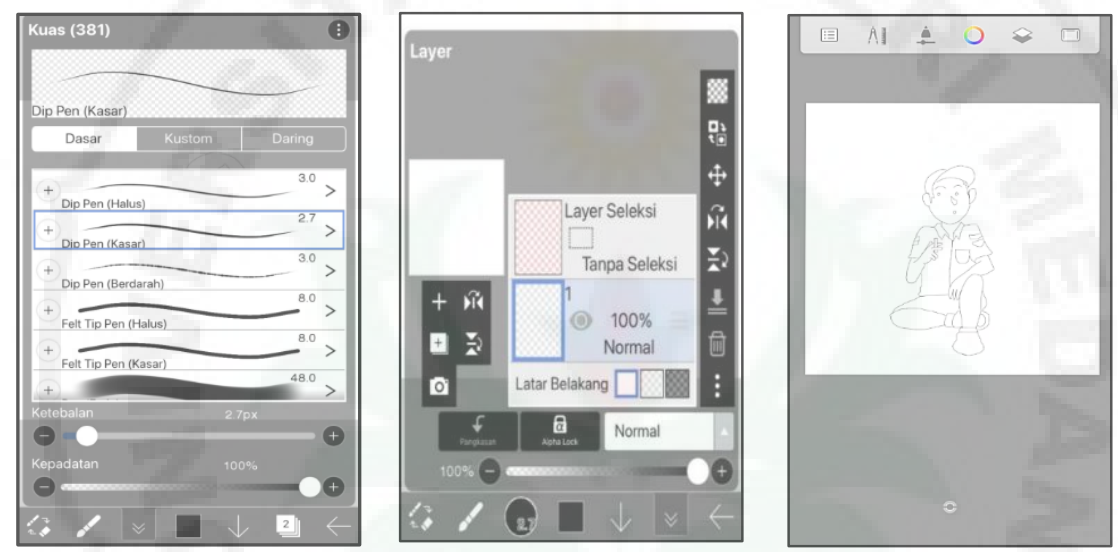

Figure 1 Sketching images with a Coarse Dip Pen (381)

The sketch design was carried out using the HUION 430P Drawing Tablet on the HUION H610 Pro Graphic Tablet screen. After the sketch is complete, the next step is coloring. This stage is done using Corel Painter software. An example of the process can be seen in the image below:
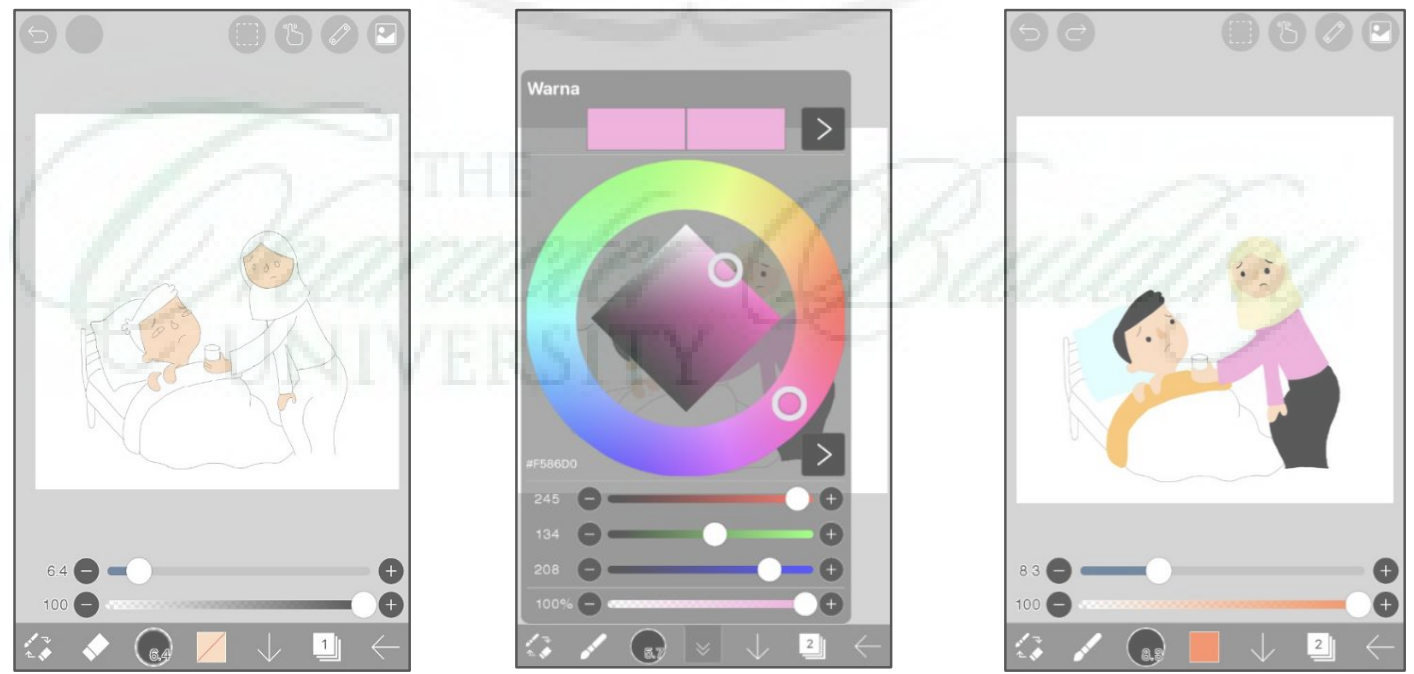

Figure 2 Sketch coloring 
After going through the coloring process, the next step is editing, such as fading, color stabilization, transitions, desired image size, large quality (pixels) and others. This stage utilizes Adobe Photoshop software to produce an image display as below:
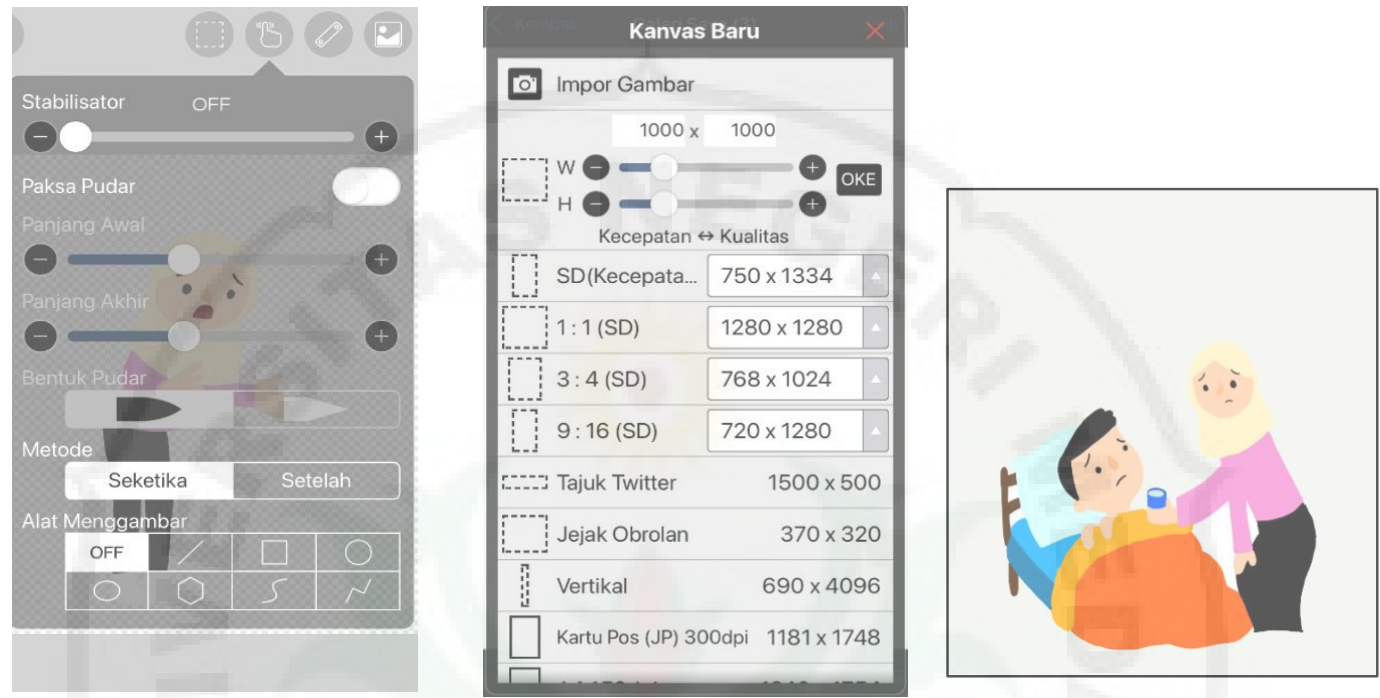

Figure 2 Editing Process

\section{Develop}

At the development stage, the researchers validated this digital database to the material validator (alpha test) and media validator before being tested on students. This trial involved 5th semester students in the French language education study program (beta test). Alpha tests are carried out several times until the application can meet all the assessment indicators from material experts and media experts. The development of the alpha test can be seen in the table below.

Table 2 Results of the alpha test

\begin{tabular}{lll}
\hline Validator & Alpha test I & Alpha test II \\
\hline Material expert & $92,3 \%$ & $100 \%$ \\
\hline Media expert & $90 \%$ & $100 \%$ \\
\hline Average & $91,15 \%$ & $100 \%$ \\
\hline
\end{tabular}

\section{Disseminate}

After the product passes the validation stage (Alpha test) and improvements have been made, the product is ready to be tested on students. At this stage, there is a Beta test in the form of a trial which is carried out on 5th semester students of the French language education study program with a total of 30 students. Before giving an assessment, respondents were given a brief explanation of the learning procedure using digital images. Then each respondent will receive a google drive link that contains learning materials for Production Orale avancée. After that, the respondent will also answer the question by expressing or describing the image in the google drive in French. After that, they filled out a questionnaire to provide assessments, suggestions, and comments on the learning media being tested. The average beta test results are shown in the following table: 
Table 3 Results of the beta test

\begin{tabular}{lll}
\hline Aspect & Average & Criteria \\
\hline Quality of content and purpose & $84,20 \%$ & Very good \\
\hline Quality of learning & $86,5 \%$ & Very good \\
\hline Technical quality & $87,6 \%$ & Very good \\
\hline The average distribution result & $86,1 \%$ & Very good \\
\hline
\end{tabular}

\section{CONCLUSION}

Based on the data from the assessment and changes that have been described, the following conclusions are obtained:

1. Development of a digital image design in the Production Orale Avancée course based on local wisdom is carried out in 4 stages, namely: define, design, develop, and disseminate. The total image generated reaches 40 images.

2. The evaluation of the validator on the media resulting from the digital image

3. design is carried out in two stages of assessment. The media feasibility of the material validator gets a percentage of $92.3 \%$ and the media validator gets a percentage of $90 \%$. Improvements to learning media were carried out in accordance with the suggestions and comments of the validators until the material validators and media validators gave a score of $100 \%$ in the second assessment, which means that the results of the digital image design are very good and suitable for use. Student responses obtained from the Beta Test also showed that they liked digital image-based learning. This is shown from the survey results which stated that $86.1 \%$ of students had a very good perception. More specifically, the use of digital images makes students feel motivated to participate by expressing French sentences from the images presented that are in the agree category.

\section{REFERENCES}

Bergström, Susanne. 2017. L'influence des méthodes didactiques sur la production orale en FLE. Thèse. Suède: Stokholms Universitet.

BOISSONETTE, Stève et RICHARD, Mario. 2001. Comment construire des compétences en classe. Montréal: Chenelière MC Graw Hill.

Dieudonné LECLERCQ et Marianne POUMAY. 2009. De L'apprentissage Par Les Medias A L'education Aux Medias. Réflexions Préalables À La Définition De Compétences À Acquérir. Journées d'Etude "Eduquer aux médias à l'heure du multimédias». Conseil de l'Education aux Médias. Bruxelles: Université de Liège.

Emiliana. 2013. Peningkatan Kemampuan Berbicara Menggunakan Media Gambar di Kelas V SDN 04 Hulu Sungai Ketapang. Pontianak: Universitas Tanjung Pura.

Thiagarajan, Sivasailam, dkk. (1974). Instructional Development for Training Teachers of Exceptional Children. Washinton DC: National Center for Improvement Educational System. 